A Journal of Culture, English Language Teaching \& Literature

ISSN 1412-3320 (Print), ISSN 2502-4914(Online)

Vol. 16 No. 1; July 2016

Copyright (C) Soegijapranata Catholic University, Indonesia

THE ANALYSIS OF GRAMMATICAL ERRORS OF FIRST YEAR STUDENTS' ESSAYS

Sukarno

English Department, Faculty of Letters, Jember University, Indonesia Tel +6285234831136

Email: msukarno08@gmail.com

Received: 28-01-2016

Accepted: 14-07-2016

Published: 31-07-2016 


\title{
THE ANALYSIS OF GRAMMATICAL ERRORS OF FIRST YEAR STUDENTS' ESSAYS
}

\author{
Sukarno \\ msukarno08@gmail.com \\ English Department, Faculty of Letters, Jember University, \\ Indonesia
}

\begin{abstract}
A language learner often faces many linguistic differences, especially if the native language and the target language are from different language families. The current study investigates the grammatical errors made by the first year students of the English Department, Faculty of Letters, Jember University, Indonesia. The data were collected from 30 participants' essays of Writing 01 class (documentary data) conducted from August to December 2014. Having been identified, the errors were classified into various categorizations, and analyzed based on descriptive-interpretative method to find the possible sources of the errors. The research revealed that the learners committed ten types of grammatical errors, and the six mostly prominent errors were plural form, subject-verb agreement, verb tense, word form, subject/verb omission, and passive voice respectively. This research also showed that the errors mostly resulted from the different linguistic principles of Indonesian and English (interlingual transfer), and partly from the faulty of overgeneralization of English rules (intralingual transfer). The overt influences of Indonesian to English as well as the overgeneralization of English rules can provide the writing teachers and course designers with insightful guidelines for better understanding of the sources of errors, which in turn, can help them to apply the more appropriate approaches to manage the foreign language learners' errors of the students.
\end{abstract}

Key words: grammatical errors, native language, target language, interlingual, intralingual

Abstrak: Karena tatanan bahasa dapat berbeda-beda antarbahasa, seseorang yang sedang mempelajari bahasa asing sering mengalami berbagai 
2 Celt, Volume 16, Number 1, July 2016, pp. 1-21

perbedaan aturan kebahasaan, khususnya apabila bahasa ibunya (L1) dan bahasa yang sedang dipelajarinya (L2) berasal dari rumpun bahasa yang berbeda. Penelitian ini bertujuan untuk mengungkap kesalahan-kesalahan gramatika yang terdapat pada esei (karangan) mahasiswa tahun pertama pada Jurusan Sastra Inggris Universitas Jember. Data penelitian ini dikumpulkan dari 30 karangan mahasiswa (data dokumenter) yang berasal dari matakuliah Writing I dari bulan Agustus sampai dengan bulan Desember 2014. Setelah dikumpulkan, data diklasifikasikan ke dalam beberapa kategorisasi gramatika, dan dianalisis dengan metode deskriptif interpretatif untuk menemukan penyebab atau sumber berbagai kesalahan tersebut. Hasil penelitian ini menyatakan bahwa terdapat sepuluh jenis kesalahan gramatika yang dilakukan mahasiswa dalam eseinya, dan enam kesalahan yang menonjol adalah kesalahan dalam hal penulisan bentuk nomina jamak, kesesuaian bentuk subjek dan verba, tenses, bentuk kata, penghilangan unsur subjek/verba, dan konstruksi kalimat pasif. Studi ini membuktikan bahwa sumber kesalahan tersebut terutama berasal dari perbedaan prinsip-prinsip kebahasaan bahasa Indonesia dan bahasa Inggris (pengaruh bahasa ibu/interlingual transfer), dan sebagaian disebabkan oleh kesalahan penyamarataan aturan kebahasaan bahasa (Inggris) yang dipelajarinya (intralingual transfer). Pengaruh yang besar atas bahasa Indonesia terhadap bahasa Inggris dan penyamarataan aturan kebahasaan pada bahasa yang dipelajari sepatutnya dapat dijadikan acuan bagi pengajar kelas Writing dan pihak penyusun materi matakuliah Writing agar mereka dapat memilih dan menerapkan pendekatan yang lebih tepat guna menangani berbagai kesalahan mahasiswa terutama yang masih berada pada tahun pertama.

Kata kunci: kesalahan gramatika, bahasa ibu, bahasa sasaran, interlingual, intralingual

\section{INTRODUCTION}

Basically, learning a language consists of active and productive skills. Writing is generally considered to be one of the active or productive skills of language usage. It is considered active and productive because learners have to apply many aspects of language, such as: general knowledge, vocabulary, and grammar in this subject. Writing is also considered very important in every curriculum of university because it is believed that this subject can be seen as a tool for language development, for critical thinking, and for learning in all disciplines. In universities, writing becomes significant because most subjects depend on it. Taking notes, writing essays, answering questions, writing reports, and finally writing thesis also need the help of 
writing class. The skills presented in writing will also develop the students' skills in acquiring the needed strategies to present the data, to analyze, to interpret, and to make inference from the data collected from their researches (Bacha, 2002). There are some aspects can be evaluated from the students' essays, such as: the content (the information presented in the essays), the organization (the ways of organizing ideas), and the language accuracy (the appropriate and acceptable forms of grammar used in the essay). The content and the organization, however, will be hard to follow if the language (the grammar) they used is not accurate. Accuracy in writing occurs when the language learner conforms to the rules of the target language; and error occurs when it does not. Those rules may be at different levels: pronunciation, morphology, syntax, lexicon, discourse, or sociolinguistics (Carla, 2015). Since the focus of the study is the grammatical errors, the appropriate levels for the errors are morphology and syntax levels made by the students in their essays.

\section{LITERATURE REVIEW}

\section{A. Contrastive Analysis and Error Analysis}

Concerning to the learner's errors, there are two major approaches to study, namely contrastive analysis and error analysis. Error analysis cannot be studied properly without touching upon the notion of contrastive analysis. Both of them have been commonly recognized as branches of Applied Linguistic Science (Khansir, 2012). Contrastive linguistics has been defined as a linguistic study which concerns with the comparison of two or more languages or subsystems of languages in order to determine both differences and similarities between them (Fisiak, 1981). The contribution of contrastive analysis in the language teaching is the description of the grammatical errors which made up the differences between the grammar of the native language (L1) and that of the target language (L2). In relation to the sources of errors, Bose (2005) explained that one of the sources of the learner's errors is the interference (or transfer, according to Ellis (1997) of his native language which can be depicted as the negative and positive transfer between L1 and L2. The negative transfer occurs when the grammatical forms of L1 and L2 are different, while the positive transfer happens if they are similar. Another attitude to errors is that they are the result of the influence of $\mathrm{L} 1$ on the learning process called interference. This process is also based on the fact that learning foreign language is strongly influenced by the habit of the learner's native language (Corder, 1987). 
Error analysis, on the other hand, claimed that the learner's errors are not merely caused by the native language because many errors actually made have no parallel with the native language structures (Khansir, 2012). Referring to both contrastive linguistics and error analysis, errors may be caused by both contrastive difference as well as the structures of the target language itself. Richards and Schmidt (2010) and Shekhzadeh and Gheichi, (2011) distinguish between two sources of errors: interlingual transfer and intralingual transfer. Interlingual transfer explains that errors may result from the language transfer of similar rules from the learner's native language to the target language. For example, the incorrect English sentence 'John go to school every day*' was produced as the transfer of his native (Indonesian) language rule 'John pergi ke sekolah setiap hari' in which Indonesian does not have subject-verb agreement. In contrast, intralingual transfer describes that errors are caused by the mutual interference of items in the target language (Keshavarz, 1994) which is also known overgeneralization or ignorance of rule restriction of the target language. Overgeneralization occurs when the learner has mastered a general rule but he does not yet know all the exceptions to that rule (Ziahosseiny, 1999 p. 126). For example, a learner may produce 'He must to go to school' ${ }^{*}$ based on the overgeneralization of the English structure 'He wants to go to school'.

\section{B. Previous Studies}

There have been many recent publications in contrastive analysis and error analysis on the errors made by learners of English as a foreign language in many different levels. The study of the morphophonological or syntactic transfer in the acquisition of articles by Syrian speakers was conducted by Sarko (2008) in which he found that they transfer the syntactic properties of L1 into English grammar. Ting et al (2010) investigated the grammatical errors in spoken English of university students in oral communication course who are less proficient in English. The results of the research showed that the five common errors made by the learners are preposition, question, article, plural form of noun, subject-verb agreement, and tense. The result also showed an increase in grammatical accuracy in the students' spoken English towards the end of the course. Next, Isabelli-Garcia and Slough (2012) investigated the acquisition of non-generic definite article by Spanish learners of English as a foreign language which proved that the obligatory use of the definite articles does increase accuracy rates. Further study on morphological and syntactic errors was carried out by Al-Badawi (2012) who investigated phonetic, morphological and syntactic errors made by the undergraduate Saudi students at King Khalid University. 
Further publications of contrastive and error analysis on English essays or writing productions as well as translation for non-English speakers (Chinese, Spanish, Arab, Jordan, French, among others) have been conducted by the following researchers. Research on error analysis of Chinese learners of the Korean language manifested errors within learners' written works was conducted by Lee (2010). This research revealed that errors resulted both from the native language transfer as well as from the target language transfer. Zahwareh (2012) investigated the written English errors of tenth grade students in females and males schools in Ajloun, Jordan. This study revealed the grammatical errors occurring in the areas of morphology, function words, tenses, and lexical items. The next study (Sokeng, 2014) presented the discussion of the difficulties that bilingual level 1 Francophone students in the Department of Bilingual Studies of the University of Yaounde 1 face in English.

The analysis of their compositions revealed that the most salient grammatical errors found in the students essays covering the fields of verb tense and form, subject-verb agreement, prepositions, word order, plurality, articles, passive voice, auxiliaries and double negation. These results proved that the teaching and learning of English writing skill of secondary students in Cameroonian primary and secondary schools need more reinforcement and development. Finally, Presada and Badea (2014) conducted a research on the effectiveness of error analysis within the translation classes on the theoretical framework of contrastive and error analysis. This study investigates the most frequent types of errors and their causes. The findings of this research constitute a data base which is necessary to conceive a more effective teaching and learning process that focuses not only on translation classes, but also on the acquisition of English as a foreign language in general.

An overview of the importance of error analysis in teaching English as a foreign language in Indonesia was carried out by Hasyim (2002). This article presented some sample of English sentences containing grammatical errors made by the students and analyzed them based on the linguistic theories. By this discussion, the students are expected to increase their knowledge on their English grammar. A study on phonological errors particularly the English consonantal sounds that do not exist in Indonesian phonetics system produced by English department students was conducted by Tiono and Yostanto (2008). The study revealed that the students produced thirty-four kinds of phonological errors and that the deviations occurred most frequently before, after, or in between vowels. Andi-Pallawa 
and Alam (2013) also conducted a comparative analysis between English and Indonesian phonological systems. This study proved that some differences of phonemic and phonetic features between English and Indonesian make 20 English Department students of Tadulako University, Indonesia, as the respondents, still have problems in pronouncing English words. Another study on syntax errors made by L2 learners in conversation was conducted by Wiannastiti (2014). This study revealed that L2 learners made some errors in grammar and exchanging information because they are influenced by L1. They tended to transfer from L1 to L2 rather than thinking to create the utterances in L2.

Despite the fact that there are some preliminary researchers on contrastive analysis and error analysis which investigated English errors made by the Indonesian learners of English as a foreign language, researches on English grammatical errors made by the Indonesian-English learners in essays or writing works have received comparatively less attention, if not yet done. This study commences with identifying the unacceptable (grammatical) forms produced in the first task of students' essays. In the second and third writing tasks, a special attention addressed to the students who made unacceptable forms in their first essays, to make sure whether they made ungrammatical forms systematically or unsystematically (errors vs. mistakes, according to Ellis, 1997). The essays with the grammatical errors (made by the students systematically) are considered as the source of the data, and the errors committed by the students were classified into some grammatical types. Next, the errors were discussed and interpreted to find the sources of the error production to widen the learners' knowledge of English and to improve their language accuracy in writing essays.

\section{METHODOLOGY}

This is a qualitative research using a case study approach. The case study investigated some grammatical errors made by the learners (Densombe, 2007). The population of the research consisting of 120 students who took Writing 01 classes from August to December 2014. The students were distributed into three classes (A, B, and C). All were new undergraduate students of the Department of English, Faculty of Letters, Universitas Jember (Indonesia) who enrolled in the 2014-2015 academic year. They have been studying English for 6 years in Junior and Senior High Schools, where English is a foreign language, Indonesian is a national language, and they also speak, at least, one local language, e.g. Javanese, Madurese, and Balinese. 
There are high similarities in terms of the structures of their native languages the students speak. The languages are only different particularly in the lexicons or vocabularies.

The technique of data collection in this study applied the documentary method, using written material (the students' essays) as a basis of the research (Blaxter et al, 2006: 154). This research was based on the grammatical errors found in the essays and snowballed with the interview data. During the first semester of the 2014-2015 academic year, the students were given some writing tasks on various topics, such as holiday, hobby, sport, and individual experience. The general topics were chosen because they are simple, informative, and clear to be stated which could encourage them to write. The main purposes of these exercises were not to give the information (to answer) themselves, but how the participants expressed their ability to use their English in expressing their ideas. Out of 120 papers (from the first writing task) were found 70 students who made some (serious) unacceptable forms.

Ellis (1997) raises the need to distinguish between errors and mistakes and makes an important distinction between the two. He says that errors reflect gaps in the learner's knowledge; they occur because the learner does not know what is correct. Mistakes reflect occasional lapses in performance; they occur because, in a particular instance, the learner is unable to perform what he or she knows. Following Ellis (1997), it needs to check whether the unacceptable forms made by the students were errors or mistakes by giving them the second and third tests. In the second and third writing tasks, attention was paid to the students who previously made unacceptable forms in their first essays (the 70 students). Having been identified, the result of the second and third tests proved that 30 out of 70 students made consistently and systematically unacceptable forms (errors). To support the data analysis, ten out of 30 students who committed grammatical errors were interviewed. Next, the grammatical errors made by the students in their essays were classified into some grammatical types, and interpreted to find the possible causes of the errors. The design was chosen to provide a clear framework for collecting, analyzing, discussing, and interpreting data to address the research goals (Creswell and Clark, 2011).

\section{FINDINGS AND DISCUSSION}

In this section, the results of grammatical errors made by the students in their essays are presented. Having been identified and selected, the data in 
the form of grammatical errors found in the 30 essays of the students were classified and calculated (to find the frequencies). It was found 1,007 grammatical errors, which could be classified into 10 grammatical types. Table 1 presents the types, numbers and percentage of the grammatical errors committed by the participants in their written works (essays).

Table 1:

Types and Frequency of Grammatical Errors in the Students' Essays

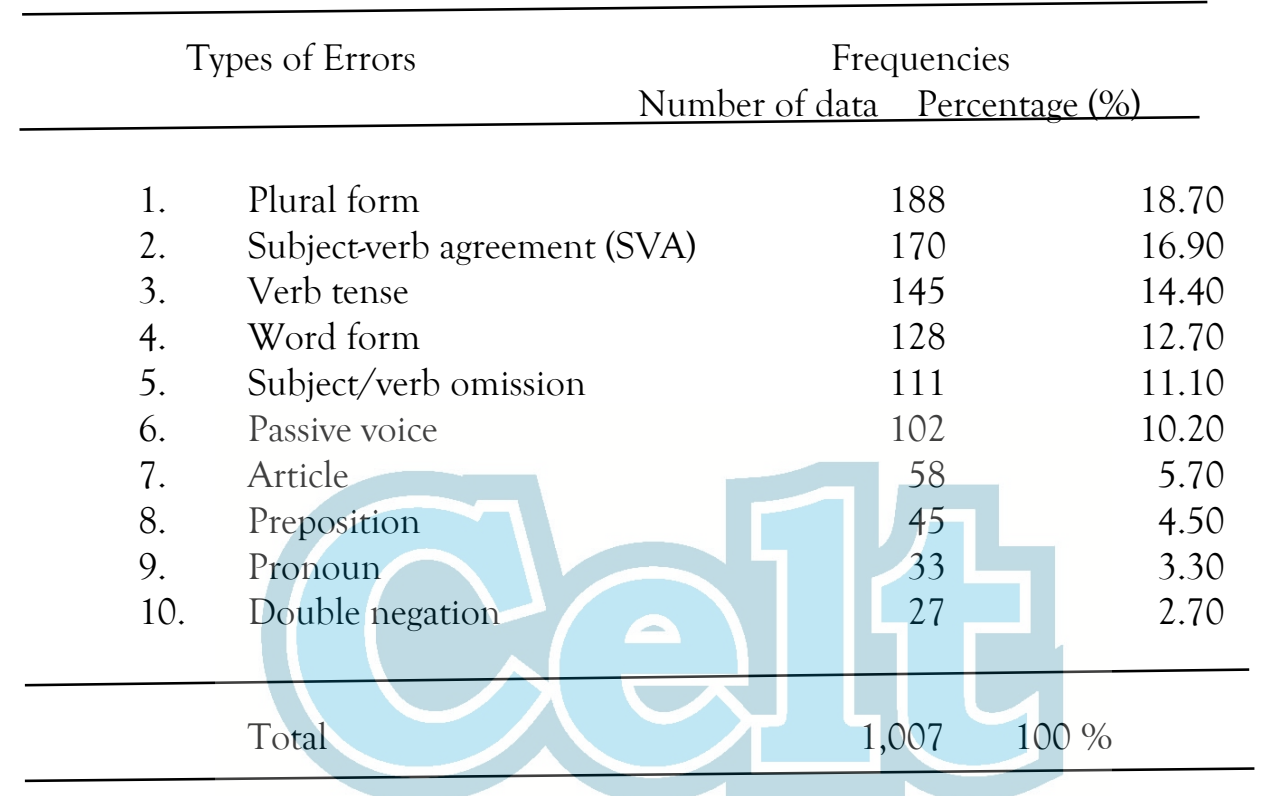

Table 1 shows that the total number of grammatical errors made by the 30 students in their essays was 1,007 errors. The grammatical errors were distributed in ten grammatical types, and the frequencies ranges from plural form, the most frequently occur, and double negation, the least frequency.

In the discussion, it is only selected the types of errors which have the occurrence higher than one hundred times (or more than 10\%). They are errors in plural form (188 or $18.7 \%)$, in subject- verb agreement (170 or $16.9 \%)$, in verb tense (145 or $14.4 \%)$, in word form (128 or $12.7 \%)$, subject/verb omission (111 or $11.1 \%$ ), and passive voice (102 or 10.20\%). Each of the six findings was presented and discussed below respectively. First of all, the data extracts (if possible accompanied by the Indonesian versions as the source of the errors, written in brackets) are presented on the left columns, while the corrections appear on the right column. Asterisk $\left({ }^{*}\right)$ indicates an error sentence, bold shows the grammatical element of the errors and their correction, and the symbol $\wedge$ refers to a missing element in the sentence. 


\section{A. Error in Plural Form}

The mostly prominent errors made by the students in their essays are errors in using the correct plural form of nouns. Out of 188 errors in plural form, they deleted the plural noun markers '-s/-es' in their essays. The italic elements show the key words which require plural forms in English.

Table 2:

Errors in Plural Form

No. Data Extracts

The (possible) Correction

(Indonesian)

1. ${ }^{*}$ They visited both the student.

They visited both (Mereka mengunjungi kedua students. mahasiswa itu).

2. *She enjoys food from many different She enjoys food country.

(Dia menyukai makanan dari berbagai negara.)

3. *You have a number of choice that You have a number you can

take. (Anda mempunya sejumlah can take. pilihan yang dapat anda lakukan)

Table 2 demonstrates errors in plural form made by the students. English distinguishes two different forms of (countable) nouns: singular vs. plural forms. Unlike English, Indonesian does not have a marker for the plural nouns, both have the same form. Whether the meaning of a noun is singular or plural is determined by the key words (e.g. kedua 'both', banyak 'many', and sejumlah 'a number of'). In contrast, such key words require plural nouns in English. The students have had such habit in their native language which they transfer to L2 (negative transfer).

According to Ellis (1997) two languages having distinct linguistic structures may result in a high frequency of errors in the target language which in turn indicates an interference of L1 on L2. In a short, the course of this error belongs to interlingual transfer. 


\section{B. Error in Subject-Verb Agreement}

The second mostly frequent grammatical error for the students in this study is related to subject-verb agreement. Rule for subject-verb agreements in English is really simple. A third person singular subject requires base form + the suffix: -s or -es, whereas other subjects do not. As Indonesian does not apply such rule, the students often neglect the agreement between a subject and its verb form in their English essays, as demonstrated in Table 3.

Table 3:

Errors in Subject-Verb Agreement

\begin{tabular}{|c|c|c|}
\hline No. & $\begin{array}{l}\text { Data Extracts } \\
\text { (Indonesian) }\end{array}$ & ible) Correction \\
\hline 4. & $\begin{array}{l}{ }^{*} \text { My friend usually drive a car to campus } \\
\text { (Temanku biasanya naik mobil ke } \\
\text { kampus). }\end{array}$ & $\begin{array}{l}\text { My friend usually } \\
\text { drives a car to campus. }\end{array}$ \\
\hline 5. & $\begin{array}{l}\text { *A teacher together with his students are } \\
\text { studying in classroom } 6 . \text { (Seorang guru } \\
\text { bersama dengan murid-muridnya sedang } \\
\text { belajar di ruang } 6 \text { ). }\end{array}$ & $\begin{array}{l}\text { A teacher together } \\
\text { with his students is } \\
\text { studying in classroom } \\
6 .\end{array}$ \\
\hline 6. & $\begin{array}{l}\text { *The books on the table in room } 6 \\
\text { belongs to me. } \\
\text { (Buku-buku di atas meja di ruang } 6 \\
\text { adalah bukuku.) }\end{array}$ & $\begin{array}{l}\text { The books on the table } \\
\text { in room } 6 \text { belong to } \\
\text { me. }\end{array}$ \\
\hline 7. & $\begin{array}{l}{ }^{*} \text { All of the details in this report needs to } \\
\text { be checked. (Semua rincian yang } \\
\text { terdapat di dalam laporan ini perlu } \\
\text { dicek lagi). }\end{array}$ & $\begin{array}{l}\text { All of the details in } \\
\text { this report need to be } \\
\text { checked. }\end{array}$ \\
\hline 8. & $\begin{array}{l}{ }^{*} \text { Every man and woman are eligible to } \\
\text { vote. } \\
\text { (Setiap pria dan wanita berhak untuk } \\
\text { memilih) }\end{array}$ & $\begin{array}{l}\text { Every man and woman } \\
\text { is eligible to vote. }\end{array}$ \\
\hline
\end{tabular}

As presented in Table 3, singular subjects take plural verbs, data (4), (5), and (6), whereas the plural subjects take singular verbs, data (7) and (8). There are two possible explanations why such errors happen. Firstly, as applies to error in plural form, English and Indonesian differ in the relation 
between subject features and their verb forms (agreement). In English, a verb must agree with its subject number (singular vs. plural) which is called subject-verb agreement (Phillips, 2001, p. 248). In contrast, the number or status of the subject in Indonesian like in many other Proto-Malay-Polynesian languages does not affect the verb structure. Indonesian does not have a subject-verb agreement rule, so the students have had a habit of ignoring such a grammatical rule in Indonesian. Then, they transferred this habit (L1) into (L2) when they were writing essays in English. In short, the source of the error results from an (negative) interlingual transfer.

Secondly, for the other students, they may know subject-verb agreement rules; however, they still made some errors in their writing essays because they have some problems to identify whether the subjects are singular or plural. The problems particularly appear if the subjects are in the form of complex structures (long noun phrases), e.g. the noun is followed by a prepositional phrase (data 5, and 6), preceded by an expression of quantity 'all of (data 7), or preceded by a certain word, such as 'every' or 'each' (data 8). As the students had problem to identify the number of subject, consequently they made errors in subject-verb agreement; singular subjects take plural verbs, whereas plural subjects take singular verbs. The source of this error, in fact, is not caused by the native lingual interference (interlingual transfer), rather than it is from intralingual (L2) feature (intralingual transfer).

\section{Error in Word Form}

This type of error may include the incorrect use of adjective, noun, and verb forms. In their essays, it was found some errors in relation to the use of adjective and adverb forms, and noun and verb forms. Table 4 presents this type of errors.

Table 4:

Errors in Using Adjective, Adverb, and Noun Forms

No. Data Extracts (Indonesian) The Corrections

9. $\quad$ *We attended a good planned conference last week. (Kita menghadiri konferencsi yang dipersiapkan dengan baik minggu lalu).

10. ${ }^{*}$ The boy screamed extremely loud. The boy screamed (Anak laki-kali menjerit keras sekali.) extremely loudly.

We attended a wellplanned conference last week. 
11. *Ahmad appeared rather unhappily at what had happened. (Ahmad tampak kurang senang atas kejadian itu).

12. *The test seems easily for the student.

(Tes itu kayaknya mudah bagi para siswa.)

13. *Because Anita studied hardly, she could achieve

a top score. (Karena Anita belajar dengan giat, dia meraih nilai terbaik).

14. *The successful of our study does not depend on the long of our study (Keberhasilan studi kita tidak tergantung pada lamaya studi kita ...).
Ahmad appeared rather unhappy at what had happened.

The test seems easy for the students

Because Anita studied hard, she could achieve a top score.

The success of our study does not depend on the length of our study ...

Table 4 demonstrates the type of errors committed by the learners in learning English which dealt with the use of adjective and adverb forms. Morphologically, adjective and adverb have different forms in English, but their forms remain the same in Indonesian. The only clue (if needed) to the distinguish between an adjective form from its adverb counterpart in Indonesian is an adjective commonly preceded by the word 'yang', while the adverb form accompanied by the word 'dengan', as in: yang baik 'good' vs. dengan baik 'well'. In the writing practice, as shown in Table 4, the students did not pay attention to such word-class changes. They used the adjective forms instead of the adverb ones, data (9), and (10). In contrast, they used the adverb forms instead of the adjective ones, data (10), and (11). The students were not aware of the differences between adjectives and adverbs since Indonesian adjectives and adverbs have the same forms. This proves the fact that the students transferred their habit in the native language (L1) into the target language (L2), and the source of error can be called interference or interlingual transfer.

In addition to L1 interference, it also appears an intralingual transfer as the source of error in using adjective, adverb, and noun forms. For some students, they know how to use adjective and adverb, but they generalized that every adverb form is always derived from an adjective plus the suffix -ly, 
as in the word loud vs. loudly. By this analogy, they thought that hard was an adjective (only), so they generalized the adverb form of hard was hardly, data (13). Another error occurs in the use of an adjective form instead of a noun form (14). The use of the adjective 'successful' and 'long' in this sentence is incorrect because both function as the head words of the phrases. Thus, they should be changed into the noun forms 'success' and 'length' respectively. Against, this occurrence of this error is not the result of the native language (L1) interference, but it results from the features of the target language (L2) or it belongs to intralingual transfer.

\section{Error in Passive Voice}

The next grammatical error deals with the active-passive constructions. Indonesian uses passive sentences more frequently and has more passive construction forms than English does. The Indonesian passive form is particularly marked by the pronoun-verb, ter-verb, and di-verb while the main English passive construction is subject + be $+V-3$. Accordingly, there is a tendency for the students to use passive sentences when writing essays in English.

\section{Table 5:}

Common Problems with Active-Passive Constructions

$\frac{\text { No. Data Extracts (Indonesian) }}{15 . \quad{ }^{*} \text { The books must be brought by us. }}$ (Buku-buku itu harus kita bawa.)

*Is my book borrowed by you?

6. (Apakah bukuku masih anda pinjam?)

17. *The report will be submitted tomorrow morning by me. (Laporan itu akan saya serahkan besok pagi).

18. *Siti's finger was cut when she skinned a mango.

(Jari Siti teriris ketika mengupas mangga).

19. *It was happened by accident. (Hal itu terjadi secara tidak sengaja)

20. *The problem is hard to be solved. (Masalah itu sulit untuk dipecahkan).
The Correction

We must bring the books.

Do you still have my book?

I will submit the report tomorrow morning.

Siti cut her finger when she skinned a mango.

It happened by accident.

The problem is hard to solve. 
21. *The ball was kicked by Andi strongly (Bola itu ditendang Andi dengan keras).
Andi kicked the ball strongly.

As presented in Table 5, the passive constructions in Indonesian are indicated by pronoun-verb forms such as kita bawa, anda pinjam, and saya serahkan (data 15, 16, and 17), by ter-verb forms such as teriris (18) and terjadi (19), anSd by di-verb form such as dipecahkan and ditendang (20 and 21). A passive construction in English is commonly used when the agent of the activity is not explicitly identified. This is called the agentless passive form (Finegan et. al, 1992 pp. 190-191). Consequently, the Indonesian passive construction cannot automatically be transferred into passive sentences in English. Since all the agents in the sentences (data extracts) above are clearly identified, they should be expressed in active constructions rather than in the passive ones (in English). Such errors may happen since they are strongly influenced by their native language habit. Both Indonesian and English have passive sentence constructions, but the use of the passive voices can differ from one language to another. As Djatmika et al. (2014) stated that the difference on the grammatical systems cause some students make grammatical errors in writing English. Therefore, the students have to initially comprehend the linguistic knowledge of $\mathrm{L} 2$, so that they will be able to produce L2 text in a natural way.

\section{E. Error in Subject/Verb Omission}

The next prominent error found in the student essay writing is the omission of subject or verb, or both from the construction of English sentences. The finding of this research shows that there are 111 errors found in the students' essays. The errors cover the absence of subject from the sentence construction or replacing the subject with an object of preposition, the omission of a finite verb from a sentence, as well as the deletion of both subject and finite verbs from a sentence, as demonstrated in Table 6.

Table 6:

Errors in Subject/Verb Omission

\begin{tabular}{ll}
\hline $\begin{array}{l}\text { No. Data Extracts } \\
\text { (Indonesian) }\end{array}$ & The Correction \\
\hline 22. * After $\wedge$ wake up, I directly $\wedge$ bath. & $\begin{array}{l}\text { After I wake up, I } \\
\text { directly take a bath. } \\
\text { (Setelah bangun tidur, saya langsung } \\
\text { mandi). }\end{array}$
\end{tabular}


23. *For those who come late are not allowed to join this test. (Bagi mereka yang datang terlambat tidak boleh mengikuti test).

24. ${ }^{*}$ The grammar book which ${ }^{\wedge}$ written by the Muprhy is very useful. (Buku gammer yang ditulis oleh Murphy sangat bermanfaat).

25. *Where ${ }^{\wedge}$ you met my brother and sister yesterday? (Di mana kamu bertemu saudara-saudaraku kemarin?)

26. ${ }^{*}$ When $\mathrm{I}^{\wedge}$ walking home at night, $\mathrm{I}$ see $\wedge$ ghost.

(Ketika saya berjalan pulang malam hari, saya melihat hantu).

27. ${ }^{*} \mathrm{He}^{\wedge}$ at home alone. (Dia di rumah sendirian)

28. ${ }^{*} \mathrm{He} \wedge$ very clever in Matematic subject.

(Dia pandai sekali dalam pelajarán matematika).
Who comes late is not allowed to join this test.

The translation book (which was) written by Murphy is very useful. Where did you meet my brother and sister yesterday?

When I was walking home at night, I saw a ghost.

$\mathrm{He}$ is at home alone

He stays at home alone

He is very good at Mathematics.

As demonstrated in Table 6, the students omitted the subject and finite verb, data (22), and replaced the subject with an object of preposition, data (23). In the next sentences, data $(24-28)$, the students committed grammatical errors because they omitted finite verbs from their sentences, as shown by the symbol $\wedge$. The Indonesian version of (22) is well accepted in Indonesian because the subject of the first clause can be controlled by the subject of the main clause, and the word mandi 'bath' can function as a verb. The next sentences in which the finite verbs are missing are also accepted in Indonesian because this language does not have the verb form distinctions (e.g. finite vs. non-finite verbs). Unlike English, Indonesian can have the verb ditulis 'written' as a full (finite) verb which makes the sentence (24) is wellform by itself, and (similarly) an interrogative sentence (25) does not need an auxiliary verb. In contrast, the (non-finite) verb 'written' cannot be the predicate of the subordinate clause without the (finite) verb 'was' (24). The only possibility for this construction without a finite verb is to change the (adjective) clause into a reduced form by deleting the connector 'which' as 
shown in the correction. Next, Indonesian sentences can have adverbial predicate (27), or adjectival predicate (28) while an English sentence always needs a finite verb as a predicate element (a verbal predicate). All examples give the idea that they committed the errors because they were strongly influenced by Indonesian in learning English as a foreign language. From the discussion above, it can be said that learners usually transfer the L1 rules to the L2 ones. Some omissions of subject, to be, and auxiliary verbs were used by the L2 learners result from their habit in their native language (interlingual transfer).

\section{F. Errors in Verb Tense}

Tense is a frequent category in the languages in the world, but it is far from universal (Trask, 1993, pp. 276). Like many languages in Asia, Indonesian is an example of a language which lacks tense entirely. Indonesian verbs do not correlate with the distinctions of time. Whether the time is past or non-past, the verb remains the same. In contrast, English exhibits a tense system. Naturally, the Indonesian-English learners often made errors in choosing the right tense, and the right forms of verbs, as presented in Table 7.

Table 7:

Error in Tense System

No. Data Extracts

The Correction

(Indonesian)

29. *Yesterday I see you with your friends in Matahari Department Store.

(Kemarin saya melihat kamu bersama teman-teman di Pusat perbelanjaan Matahari).

30. *Last holidays, we enjoy ourselves very well in our grandparents' town. It is very good and interesting.
Yesterday I saw you with your friends in Matahari Department Store.
*Last holidays, we enjoyed ourselves very well in our grandparents' town. It was very good and interesting. 
31. *I have done my homework yesterday afternoon.

(Saya telah menyelesaikan PRku kemarin sore)

32. *If I become a bird, I will fly all over the world.

(Jika saya menjadi seekor burung, saya akan terbang ke seluruh dunia)
- I have done my homework.

- I did my homework yesterday afternoon.

If I were a bird, I would fly all over the world.

As reported in Table 7, the students made errors because they transferred the habit of their L1 rule to L2 in which the verb forms ('see', 'enjoy', and 'is') do not correlate with the (past tense) time markers (e.g. 'yesterday' and 'last holidays') in data (29) and (30). Next, as shown by data (31), the learners mixed both the result of an activity and the specific time into one sentence. Unlike Indonesian, English only chooses one of them (perfect tense or simple past tense, but not both) (Murphy, 1994, pp. 14). If the result of the activity is the focus of the utterance, the present perfect tense should be used. Alternatively, if the speaker identifies a specific point of time, he should choose the simple past tense. In other words, we cannot combine both the result and the particular time referring to the activity into one sentence. In short, the learners made such error because Indonesian does not have tense system, so they transferred the habit of their native language (L1) into L2. Finally, the students also made error in term of 'condition' which is expressed through the wrong verb forms/tenses (data 32), which should be 'were' and 'would fly'. As the beginners, they are not familiar yet with the construction of expressing a 'conditional' sentence realized through the verb forms. Accordingly, the acquisition of tense will be very difficult for the learners since there are quite big difference rules between the two languages.

\section{CONCLUSION}

Based on the identified and classified errors found in 30 essays produced by the 30 first year students of the writing classes of the English Department, Faculty of Letters, Jember University, Indonesia, it was found 1,007 grammatical errors. The errors committed by the students could be classified into ten types, and the six mostly prominent errors are errors in 
plural form, subject-verb agreement, verb tense, word form, subject/verb omission, passive voice, article, preposition, pronoun, and double negation.

From the discussion, it can be concluded that the students made errors in the grammatical patterns because they are strongly influenced by Indonesian (L1) patterns that they acquired before, even the rules have become a well-rooted habit in their minds. The L1 patterns were reflected in their essays which can be depicted through errors in plural form, passive voice construction, subject/verb omission, and verb tense. Such errors were strongly caused by the interference of L1 (interlingual transfer) because they do not have such grammatical features in L1 that are very important in L2.

In addition to interlingual transfer, the grammatical errors were also caused by the student's inability of applying L2 rules comprehensively. They made errors because they made overgeneralizations of L2 rules. Such errors occur in subject-verb agreement and in word form. Therefore, the grammatical errors are not all of them from their mother tongue interference, but also from their intralingual transfer of the target language. It is right that grammatical errors are both from the interference of mother tongue (interlingual transfer) and from the mutual interference of items in the target language (intralingual transfer), however, in case of Indonesian speakers, interlingual transfer plays greater causes than intralingual transfer since L1 and L2 are from different language families which make possible to have distinct linguistic principles.

The result of this analysis can be advantageous for learners, teachers, and course designers. Considering the sources of the errors they made, it is expected that students will be able to analyze and correct their own errors which will improve their English more accurately. This research is also hoped to provide teachers and course designers with better understanding of the sources of the students' errors, which motivate them to evaluate the teaching approaches applied so far, and to find the more appropriate ones to deal with the foreign language learners' errors.

\section{REFERENCES}

Al-Badawi, K. (2012) An Analysis of Phonetic, Morphological and Syntactic Errors in English: a Case Study of Saudi BA students at King Khalid University. International Journal of Social Science and Humanity. 2 (6), 536-538. 
Andi-Pallawa, B. \& Alam, A.F.A. (2013). A Comparative Analysis between English and Indonesian Phonological Systems'. International Journal of English Language Education, 1 (3), 103-129.

Bacha, N.N. (2002). Developing Learners' Academic Writing Skills in Higher Education: A Study for Educational Reform. Language $\mathcal{E}$ Education, 16 (3), $161-177$.

Bose, M.N.K. (2005). A Text Book of English Language Teaching for Indian Students. Chennai: New Century Book House (P) Ltd.

Blaxter, L., Hughas, C., \& Tight, M. (2006). How to Research. New York: Open University Press.

Carla (2015). Overview on Error Analysis. Retrieved from http://www.carla.umn.edu/ learnerlanguage/error_analysis.html

Corder, S.P. (1987). Error Analysis and Interlanguage. Oxford: Oxford University Press.

Creswell, J.W. \& Clark, V.L.P (2011). Designing and Conducting Mixed Method Research. Thousand Oaks, CA: Sage Publication.

Densombe, M. (2007). The Good Research Guide: for Small-Scale Social Research Project. New York: Open University Press.

Djatmiko, Wibowo, A.H., \& Dewi, I.K. (2014). The Quality of English Translation of Bilingual Books for Physics and Social Sciences. Humaniora: Journal of Culture, Literature, and Linguistics, 26 (3), 351-361.

Ellis, R. (1997). Second Language Acquisition. Oxford: Oxford University Press.

Finegan, E., Besnier, N., Blair, D., \& Collins, P. (1992). Language Its Structure and Use. Sydney: HBJ Publishers.

Fisiak, J. (1981). Contrastive Linguistics and the Language of Teacher. Oxford: Oxford University Press.

Hasyim, S. (2002). Error Analysis in the Teaching of English. Kata, 4 (1), $42-50$.

Isabelli-García, C. \& Slough, R. (2012). Acquisition of the Non-Generic Definite Article by Spanish Learners of English as a Foreign Language. On Omázein, 25 (1), 95-105.

Keshavarz, M. H. (1994). Contrastive Analysis and Error Analysis. Tehran: Rahnama Publications. 
Khansir, A.A. (2012). Error Analysis and Second Language Acquisition. Theory and Practice in Language Studies, 2 (5), 1027-1032.

Lee, J.H. (2010). Error Analysis of Chinese Learners of the Korean Language: Focus on Source Analysis of Content-Based Errors. Electronic Journal of Foreign Language Teaching 7, Suppl. 1, 110-124. Centre for Language Studies National University of Singapore.

Muphy, R. (1994). English Grammar in Use: A Self-Study Reference and Practice Book for Intermediaet Students. Cambridge. Cambridge University Press.

Phillips, D. (2001). Longman Complete Course for The TOEFL Test. New York: Addison Wesley Longman.

Presada, D. \& Badea, M. (2014). The Effectiveness of Error Analysis in Translation. Porta Linguarium. 22, 49-59.

Richards, J.C., \& Schmidt, W.R. (2010). Longman Dictionary of Language Teaching and Applied Linguistics. Routledge: Pearson Longman.

Sarko, G. (2008). Morphophonological or syntactic transfer in the acquisition of English articles by L1 speakers of Syrian Arabic? In Proceedings of the 9th Generative Approaches to Second Language Acquisition Conference. Ed. Roumyana Slabakova et al., 206-217. Somerville, MA: Cascadilla Proceedings Project.

Shekhzadeh, E. \& Gheichi, M. (2011). Account of Sources of Errors in Language Learners' Interlanguage. International Conference on Languages, Literature and Linguistics IPEDR, 26, 159-162.

Sokeng, S.C.P. (2014). Grammatical Errors of Bilingual Francophone Learners of English in the University of Yaounde 1. Theory and Practice in Language Studies, 4 (9), 1778-1785.

Ting, S, Mahadhir, M, \& Chang, S. (2010). Grammatical Errors in Spoken English of University Students in Oral Communication Course. Gema Online ${ }^{\text {TM }}$ Journal of Language Studies, 10 (1), 53-70.

Tiono, \& Yostanto, (2008). A Study of English Phonological Errors Produced by English Department Students. Kata, 10 (1), 79-112.

Trask, R.L. (1993). A Dictionary of Grammatical Terms in Linguistics. London: Routledge. 
Wiannastiti, M. (2014). Error Made in Conversation by Indonesian Learners Learning English Based on Syntax and Exchanging Information. HUMANIORA, 5 (2), 861-871, Binus Jakarta, Indonesia.

Zahwareh, F.A.S (2012). Applied Error Analysis of Written Production of English Essays of Tenth Grade Students in Ajloun Schools Jordan. International Journal of Learning $E$ Development, 2 (2), 280-299.

Ziahosseiny, S. M. (1999). A Contrastive Analysis of Persian and English and Error Analysis. Tehran: Nashr-e Vira. 